\title{
Reactivity of 1,2-diaza-1,3-dienes with azomethine ylides: [3+4] versus [3+2] cycloadditions
}

\author{
Serena Mantenuto, ${ }^{[\mathrm{a}]}$ Alberto Cayuelas, ${ }^{[\mathrm{b}][\mathrm{c}]}$ Gianfranco Favi, ${ }^{[\mathrm{a}]}$ Orazio A. Attanasi, ${ }^{[\mathrm{a}]}$ Fabio \\ Mantellini, ${ }^{[\mathrm{a}]_{\star}}$ Carmen Nájera,${ }^{[\mathrm{b}]}$ and José M. Sansano, ${ }^{[\mathrm{b}][\mathrm{c}]_{\star}}$
}

Dedication ((optional))

\begin{abstract}
The multicomponent 1,3-dipolar cycloaddition of different 1,2-diaza-1,3-dienes with in situ-generated azomethine ylides produces 1,2,4-triazepines or pyrrolidines by means of [3+4] or [3+2] cycloadditions, respectively. The regioselectivity is controlled by the electron-withdrawing group bound to the azo-moiety of the 1,2 -
\end{abstract}

\section{Introduction}

1,3-Dipolar cycloaddition ${ }^{[1]}$ (1,3-DC) is a fascinating stereocontrolled reaction where a 1,3-dipole and an alkene, allene, or alkyne react to give a five-membered heterocyclic ring allowing the presence of large series of functional groups. ${ }^{[2]}$ These multicomponent, ${ }^{[3]}$ atom economy, ${ }^{[4]}$ catalyzed ${ }^{[5]} 1,3-\mathrm{DCs}$ constitute a clear trend of innovation in both laboratory and industrial scale, cycloadditions being the most frequently employed. ${ }^{[6]}$ Some of us used this methodology in several multicomponent 1,3 -DCs of diethyl aminomalonate or a-amino esters with 2-oxoaldehydes and dipolarophiles. ${ }^{[7,8,9]}$ At this moment, the cycloaddition between azomethine ylides and electrophilic alkenes is the most frequently reported version due to its high regio- and diastereoselection. ${ }^{[10]}$ The azomethine ylide which can be generated in situ through several manners, reacts efficiently with maleimides, maleates and their derivatives, fumarates, acrylic systems, vinylic sulfones, nitroalkenes, enones, inones, etc. ${ }^{[11]}$ The main trend of all these acceptors is that a carbon-carbon double or triple bond are involved in the pericyclic transformation affording the corresponding [3+2] cycloaddition product. However, it has been reported that some examples with particular alkenes did not follow the general [3+2]

[a] S. Mantenuto, G. Favi, O. A. Attanasi, F. Mantellini. Department of Biomolecular Sciences, Organic Chemistry Section and Organic Natural Compounds.

University of Urbino "Carlo Bo", Via I Maggetti 24, 61029 Urbino (PU), Italy. Phone: (+39)-0722-303445;

e-mail: fabio.mantellini@uniurb.

[b] A. Cayuelas, C. Nájera, J. M. Sansano.

Departamento de Química Orgánica and Centro de Innovación en Química Avanzada (ORFEO-CINQA).

Universidad de Alicante, Apdo. 99, E-03080-Alicante, Spain.

e-mail: jmsansano@ua.es.

[c] A. Cayuelas, J. M. Sansano.

Instituto de Síntesis Orgánica (ISO).

Universidad de Alicante.

Author Contributions: S. Mantenuto and A. Cayuelas contributed equally to this work.

Supporting information for this article is given via a link at the end of the document.((Please delete this text if not appropriate)) diaza-1,3-diene which promotes exclusively the [3+4] cycloaddition. When the electron-withdrawing group is replaced with a phenyl group only a [3+2] cycloaddition occurs.

pattern. For example, a [3+3] cycloaddition was observed in selfcyclizations of azomethine ylides derived from isatin with various primary or cyclic secondary amines, $\left.{ }^{[12}\right]$ with quinone monoimides, ${ }^{[13]}$ or using phthalazinium dicyanomethanides. ${ }^{[14]}$ $[3+6]$ Cycloadditions were detected employing 2acylcycloheptatrienes, ${ }^{[15]}$ fulvenes, ${ }^{[16]}$ or tropone, ${ }^{[17]}$ and also 1,7-electrocyclizations have been published. ${ }^{[18,19]}$ In addition, highly functionalized 1,2,4,5-tetrazepine derivatives have been obtained via unprecedented [4+3] cycloaddition of in situ generated azoalkenes with $\mathrm{C}, \mathrm{N}$-cyclic azomethine imine. ${ }^{[20]}$ However, [4+3] cycloaddition processes involving azomethine ylides have not been reported yet.

Looking for an expansion of the scope of this 1,3-DC, 1,2diaza-1,3-dienes (DDs) 1 (Scheme 1) were envisaged as dipolarophile candidates. The chemical properties of DDs are based on to the electron-withdrawing effect of the azo group in the heterodiene system. DDs 1 present an umpolung ${ }^{[21]}$ of the traditional carbonyl reactivity. ${ }^{[22]}$ This nature makes these neutral compounds enable to nucleophilic additions at the terminal carbon atom of the azo-ene system. Thus, the reactivity of DDs 1 remains opposite with respect to the natural polarity of the known carbonyl derivatives, and their employment opens the possibility to have a carbon atom in the $\alpha$-position to the carbonyl group with a reverse of the normal polarity. Besides, the substituents of this system play an important role, and electron-withdrawing groups on the terminal carbon or nitrogen atom enhance the stability and the electrophilic character of the heterodiene system. $\left.{ }^{23}\right]$ DDs $\mathbf{1}$ are important synthetic intermediates and versatile building blocks in the construction of a large number of heterocycles. ${ }^{[24]}$ They are good Michael acceptors in 1,4-addition reactions ${ }^{[25]}$ and can react as dienes in inverse electron-demand [4+2] cycloadditions to give tetrahydropyridazines. ${ }^{[26]}$ DDs 1 have been also submitted to 1,3-DC in combination with nitrones to afford both 3-substituted5-diazenyl isoxazolidines, ${ }^{[27]}$ and 2,3,4,7-tetrahydro-1,2,4,5oxatriazepine. ${ }^{[28]}$

To the best of our knowledge, DDs have not been used as dipolarophiles with azomethine ylides generated by thermal decarboxylation of $\mathbf{2}$, so in this work the reactivity of several azomethine ylides with these azo-ene derivatives will be surveyed. On the basis of the substituents on the 1,2-diaza-1,3dienes a diversity-oriented synthesis (DOS) ${ }^{[29]}$ can be designed 
according to the different skeleton that would be achieved (Scheme 1). So, this divergent synthesis would afford through a [3+2] cycloaddition pyrrolidines $\mathbf{5}$, which are demonstrated to be biologically active compounds and very interesting building blocks in synthetic organic chemistry. ${ }^{[30]}$ The same reaction would furnish also 1,2,4-triazepines 4 through a [3+4] cycloaddition that are not so common in the literature as their preparation is difficult. ${ }^{[31]}$ They belong to the family of triazepines $^{[32]}$ which are very attractive, both from the pharmacological and chemical points of view. Recently, 1,2,4triazepines $\mathbf{E}$ were prepared by 1,3-DC of $\mathrm{C}-\mathrm{N}$-cyclic azomethine imines $\mathbf{C}$ and aza-o-quinonedimethanes $\mathbf{D}$ which provided the 1,2-dinitrogen component. ${ }^{[33]}$ In our work, the 1,2dinitrogenated fragment would be incorporated by DDs 1 employing azomethine ylides as 1,3-dipoles instead.
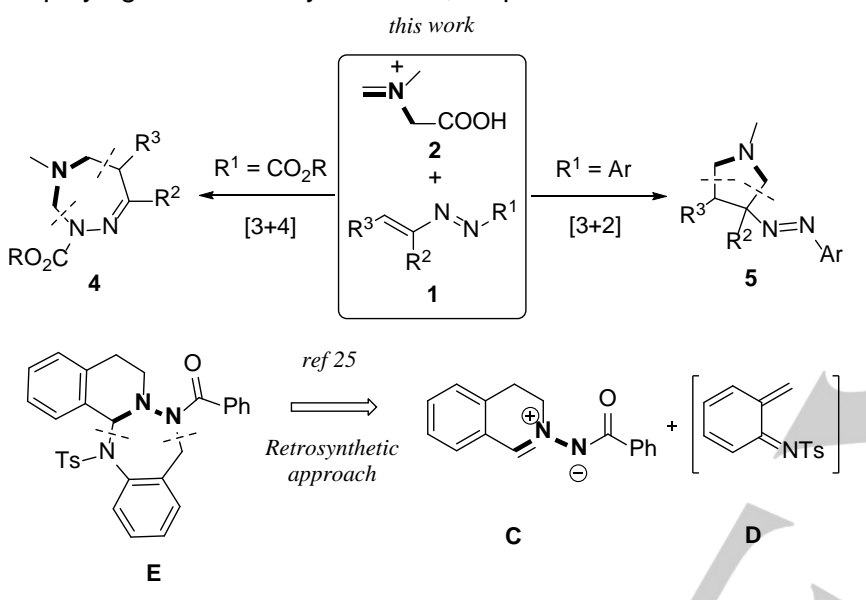

Scheme 1. Diversity-oriented synthesis of triazepines $\mathbf{4}$ or pyrrolidines $\mathbf{5}$ starting from DDs 1 and azomethine ylides 2. Comparison of triazepine's assembly pathways by means of 1,3-dipolar cycloadditions.

\section{Results and Discussion}

Based on our experience we decided to develop a conventional thermal multicomponent 1,3-DC using azomethine ylides and 1,2-diaza-1,3-dienes 1 as dipolarophiles.

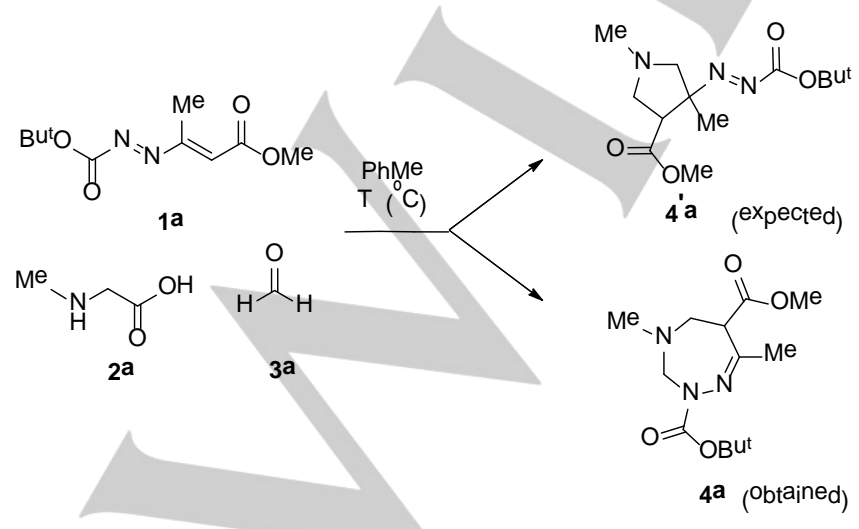

Scheme 2. Multicomponent 1,3-DC between DD 1a, sarcosine 2a, and paraformaldehyde $\mathbf{3 a}$.

For the optimization of the process we employed as model DD $\mathbf{1 a},{ }^{[34]}$ sarcosine $\mathbf{2 a}$ as $\mathrm{N}$-alkylated amino acid and paraformaldehyde $\mathbf{3 a}$ (Scheme 2). While the reaction at room temperature and at $70^{\circ} \mathrm{C}$ didn't work, by increasing the reaction temperature until the boiling point of toluene, the TLC analysis of the reaction revelead the formation of a new product that was isolated by flash chromatography. Initially, we expected the formation of pyrrolidine 4'a, but, with our surprise, the NMR spectrum of the isolated product clearly indicates that 1,2,4triazepine $4 \mathrm{a}$ was achieved in $58 \%$ yield. In fact, the signals in the NMR carbon spectrum at 158.9, 170.9, and $174.8 \mathrm{ppm}$, respectively indicate the presence of an hydrazone moiety toghether with two ester functions, in agreement with the structure of 1,2,4-triazepine $\mathbf{4 a}$. The reaction was performed also in a microwave reactor at $100{ }^{\circ} \mathrm{C}$ for $2 \mathrm{~h}$ obtaining very low conversions (<10\%) and some decomposition products. An increment of the yield (65\%) was achieved by adding two equiv of aldehyde $\mathbf{3} \mathbf{a}$ and also two equivalents of the DD $\mathbf{1 a}$.

Under these optimal reaction conditions (Sheme 2), we next examined the reactivity of different $\mathrm{N}$-alkylated amino acids and aldehydes. Unfortunately, the incorporation of other aldehydes such as cinnamaldehyde, ethyl glyoxylate, 2,2dimethoxyacetaldehyde, crotonaldehyde, pentanal and benzaldehyde in the reaction of DD $\mathbf{1 a}$ and sarcosine $\mathbf{2 a}$ was unfruitful, even heating the reaction mixture at $140{ }^{\circ} \mathrm{C}$ in a pressure tube. Also when $\mathrm{N}$-methylalanine was allowed to react with paraformaldehyde and DD 1a, no reaction product was detected by ${ }^{1} \mathrm{H}$ NMR spectroscopy of the crude product. The scope of the reaction was next evaluated in the reaction of sarcosine $\mathbf{2} \mathbf{a}$ with paraformaldehyde $\mathbf{3} \mathbf{a}$ and different DDs $\mathbf{1} \mathbf{a}-\mathbf{f}$. 1,2.4-Triazepines 4a-f were obtained moderate to good yield (30-65\%) (Scheme 3).

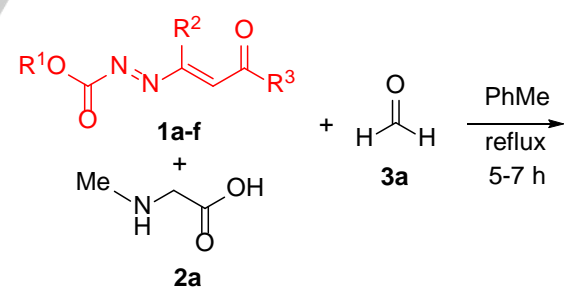<smiles>[R]C(=O)C1CN(C)CN(C(=O)OC(C)(C)C)N=C1[R]</smiles>

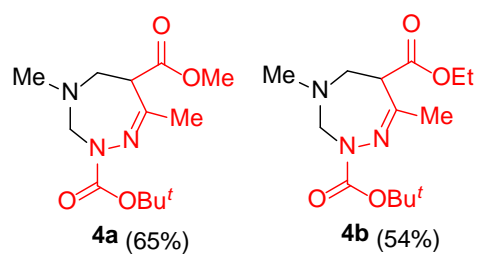<smiles>CCC1=NN(C(=O)OC(C)(O)Br)CC(C(=O)OC)CN1C</smiles>

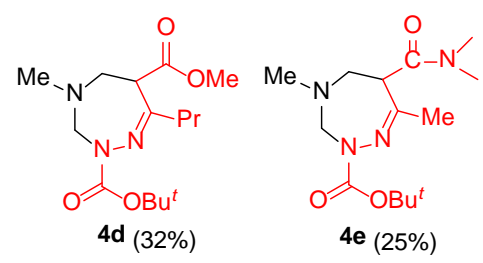<smiles>CCOC(=O)C1CN(C)CN(C(=O)OCc2ccccc2)N=C1C</smiles> 
Scheme 3. Substrate scope of different DDs 1a-f in the reaction with sarcosine 2a, and paraformaldehyde $\mathbf{3 a}$. Reaction conditions: DD $\mathbf{1 a}$ (1.0 $\mathrm{mmol})$, sarcosine $\mathbf{2 a}(0.5 \mathrm{mmol})$, paraformaldehyde $\mathbf{3 a}(1.0 \mathrm{mmol})$, toluene $(5.0 \mathrm{~mL})$, reflux.

A plausible mechanism for this [4+3] cycloaddition is described in Scheme 4. Initially, the azomethine ylide $\mathbf{G}$ is generated by a thermal decarboxylation of the iminium intermediate $\mathbf{F}$. Then, assuming that a more or less stepwise mechanism takes place, a Michael addition of the azomethine ylides $\mathbf{G}$ to the terminal carbon atom of the azo-ene system of DDs 1a-f generates the hydrazone anion intermediates $\mathbf{H}$. The subsequent $\mathrm{N}$ intramolecular nucleophilic attack on the iminium moiety furnishes the final 1,2.4-triazepines 4a-f.

$$
\text { (1) }
$$

Scheme 4. Plausible mechanism for the multicomponent 1,3-DC between DDs $\mathbf{1} \mathbf{a}-\mathbf{f}$, sarcosine $\mathbf{2} \mathbf{a}$, and paraformaldehyde $\mathbf{3} \mathbf{a}$.

The presence of an electron-withdrawing group on to the terminal nitrogen of the azo-ene system $\left(\mathrm{CO}_{2} \mathrm{R}^{1}\right)$ in $\mathrm{N}$-EWG-DDs 1a-f seems to be crucial for the reaction course, as it stabilizes the intermediate $\mathbf{H}$. Aware of this possibility, we have tested the reaction of sarcosine $\mathbf{2 a}$, paraformaldehyde $\mathbf{3 a}$ and $\mathrm{N}$-phenylDDs $\mathbf{1 g}, \mathbf{h}$ bearing a non-withdrawing substituent like a phenyl group at the nitrogen in position 1 of the azo-ene system, under the same conditions previously employed.

With our delight, we have noted that this simple change in the structure of the DDs 1 produces a different reaction pattern, affording a conventional [3+2] dipolar cycloaddition (Scheme 5). In these cases, $\mathrm{N}$-phenyl-DDs $\mathbf{1 g}$ and $\mathbf{1 h}$ afforded the corresponding 4-(phenyldiazenyl)pyrrolidine-3-carboxylates $\mathbf{5 a}$ and $\mathbf{5 b}$ in 60 and $39 \%$ yields, respectively. The signals of NMR carbon spectra have been diagnostic to reveal the structure of compounds 5. The signal of a quaternary carbon at around 80.0 $\mathrm{ppm}$ and the lack of the hydrazone moiety confirm the formation of the pyrrolidinic core. The relative configuration was unambiguously confirmed by nOe experiments, detecting a negative nOe between methyl group and $\mathrm{H}_{\mathrm{a}}$, but a large positive one between both methyl groups in molecule $\mathbf{5 a}$. This stereochemical outcome derives from the high sterospecificity of the $1,3-\mathrm{DC}$ which justify a concerted process at this temperature.

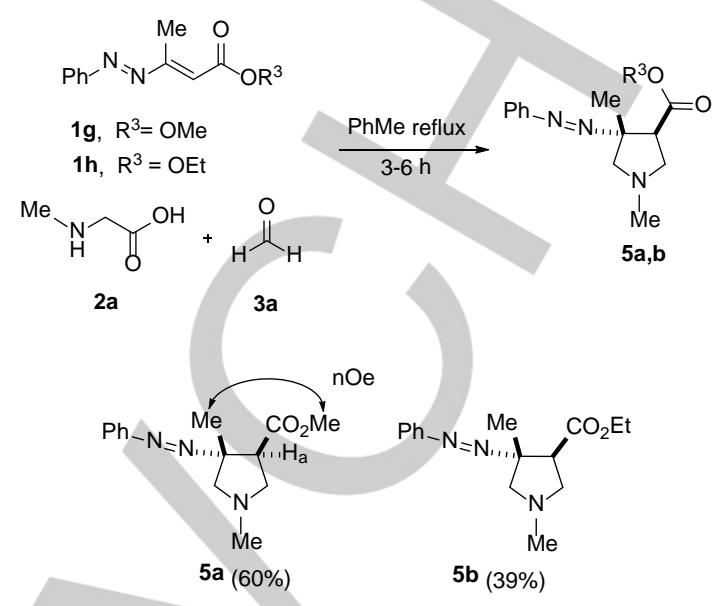

Scheme 5. [3+2] Dipolar cycloaddition of $N$-phenyl-DDs $\mathbf{1 g}, \mathbf{h}$ in the reaction with sarcosine $\mathbf{2 a}$, and paraformaldehyde $\mathbf{3 a}$. Reaction conditions: DDs $\mathbf{1 g}, \mathbf{h}$ (1.0 $\mathrm{mmol})$, sarcosine $2 \mathbf{a}(0.5 \mathrm{mmol})$, paraformaldehyde $\mathbf{3 a}(1.0 \mathrm{mmol})$, toluene $(5.0 \mathrm{~mL})$, reflux.

The different behavior observed in the 1,3-DC reaction of $\mathrm{N}$ phenyl-DDs $\mathbf{1 g}-\mathbf{h}$, encouraged us to incorporate other aldehydes such as ethyl glyoxylate, benzaldehyde. While all these attempts carried out with the aldehydes were unfruitful, the reaction between $N$-phenyl-DDs $\mathbf{1 g}, \mathbf{h}, N$-alkylated amino esters such as $\mathrm{N}$-benzyl glycine ethyl ester $\mathbf{6 a}$ or ethyl pipecolinate $\mathbf{6 b}$ and paraformaldehyde $\mathbf{3 a}$ in toluene under reflux furnished the corresponding 1-benzyl 3-(phenyldiazenyl)pyrrolidine-2,4dicarboxylates $\mathbf{7 a , b}$ and 1-(phenyldiazenyl)octahydroindolizine2,8a-dicarboxylates 7c,d. (Scheme 6). In these latter cases, the generation of azomethine ylide occurs through a [1,2]-prototropy shift after the formation of the iminium salt with paraformaldehyde $\mathbf{3 a}$.

The structure of 7a-d was confirmed by NMR methods: the absence of signals due to hydrazone moiety in ${ }^{13} \mathrm{C} N M R$, and quaternary carbons at around $80 \mathrm{ppm}$ indicates that [3+2] dipolar cycloaddition occurred. Again, nOe experiments of compound 7c revealed the cis-arrangement of both esters and methyl groups. With respect to the regioselectivity of the attack of the negative charge of the dipole, starting from $N$-EWG-DDs 1a-f, the addition occurred with the opposite trend observed for the reactions involving $\mathbf{N}$-phenyl-DDs $\mathbf{1 g}, \mathbf{h}$ (Scheme 7 ). In the case of 1-benzyl 3-(phenyldiazenyl)pyrrolidine-2,4-dicarboxylate $7 \mathrm{a}$, the singlet signal of one hydrogen in ${ }^{1} \mathrm{H}-\mathrm{NMR}$ at $4.58 \mathrm{ppm}$ excludes the regioisomer $\mathbf{7} \mathbf{a}^{\prime}$. For compound $\mathbf{7 c}$, the structure of the regioisomer obtained is confirmed by the $A B X$ coupling pattern occurring between a methyne and a methylene group. The assignments were further confirmed by ${ }^{1} \mathrm{H}-{ }^{1} \mathrm{H}$ COSY spectrum. 


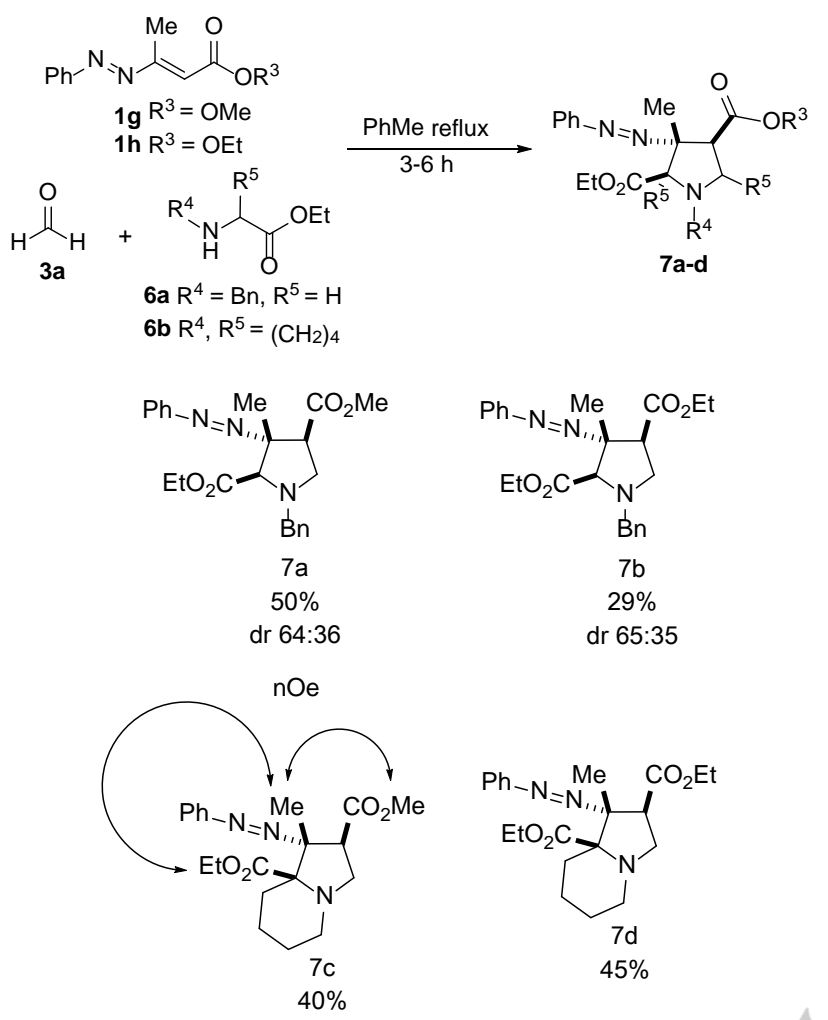

Scheme 6. [3+2] Dipolar cycloaddition of $N$-phenyl-DDs 1g,h paraformaldehyde $\mathbf{3 a}$, and glycine ethyl ester $\mathbf{6} \mathbf{a}$ or ethyl pipecolinate $\mathbf{6} \mathbf{b} .^{[a]}$

[a] Reaction conditions: $N$-phenyl-DDs 1g,h (1.0 mmol), $N$-alkylated amino esters $\mathbf{6 a}, \mathbf{b}(0.5 \mathrm{mmol})$, paraformaldehyde $\mathbf{3 a}(1.0 \mathrm{mmol})$, toluene $(5.0 \mathrm{~mL})$, reflux.
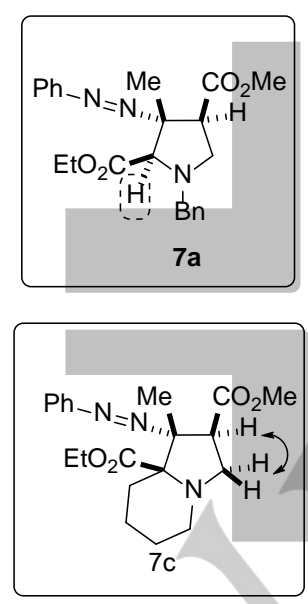

Scheme 7. Possible regioisomers of 1-benzyl (phenyldiazenyl)pyrrolidinedicarboxylate 7a,7a' and (phenyldiazenyl)octahydroindolizine-dicarboxylate 7c, 7c'.

A very important detail of this divergent synthesis was the influence of the terminal substituent in the azo component. In these last reactions, non-electron-withdrawing group present in $\mathrm{N}$-phenyl-DDs $\mathbf{1 g}$,h favored the conventional attack to the $\alpha, \beta$ unsaturated ester moiety affording pyrrolidines or octahydroindolizine 5 and 7, respectively, unlike to the reactivity exhibited by EWG-DDs 1a-f in which an electron-withdrawing substituent is bound at the terminal nitrogen of the azo-ene system. The chemical behaviour of these different DDs can be explained according to their different LUMO-coefficients. ${ }^{[34]}$ As depicted in Figure 1, the very large LUMO-coefficients of the EWG-DDs 1a located in $\alpha$-carbon to the ester group and the nitrogen atom of the aza-moiety interact with large coefficients of fleeting azomethine ylide $\mathbf{2 a}$ (coefficients around 0.7 and -0.7 in the two carbon atoms). Note the most stable transoid conformation of DD $\mathbf{1 a}$, at high temperature it must be converted in its corresponding cisoid one to complete the reaction. Again we can propose a concerted mechanism due the conservation of the relative configuration of the substituents of the DD.

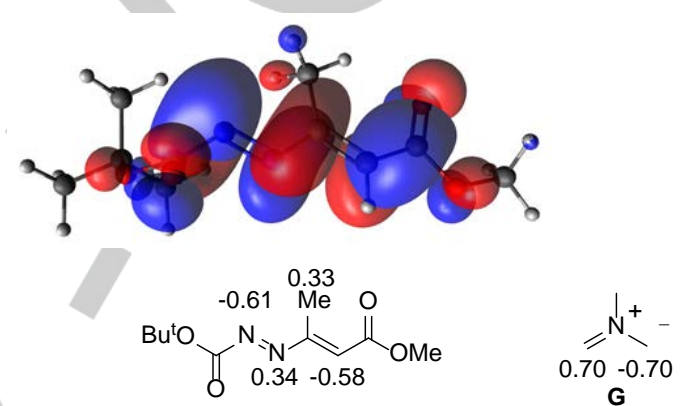

$1 \mathrm{a}$

Figure 1. LUMO orbital coefficients for $1 a$ calculated at B3LYP/6-311+g(d,p) level of theory.

In contrast, the LUMO-coefficients for $N$-phenyl-DDs $\mathbf{1 g}$-h show very similar size. The value of $\alpha$-carbon to the ester group is -0.5 , and this is the main reactive centre; similarly, the contiguous carbon atom has a 0.40 value. As five membered rings are formed faster than seven membered ones, the $[3+2]$ occurred preferentially rather than the [4+3] (Figure 2). We presumed that a step-wise process occur rather than a concerted one.

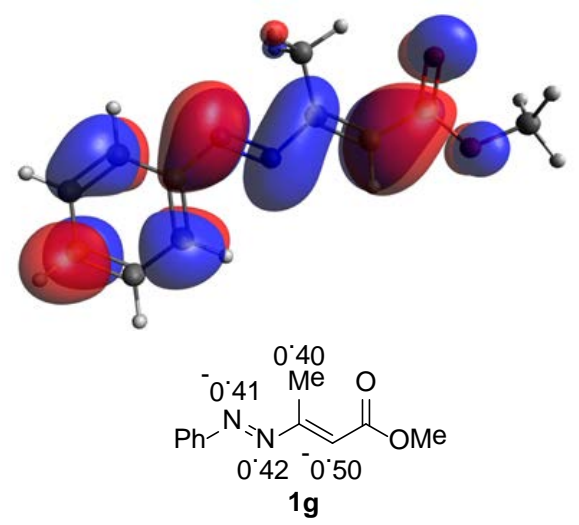

Figure 2. LUMO orbital coefficients for $1 \mathbf{g}$ calculated at B3LYP/6-311+g(d,p) level of theory for the two conformers. 


\section{Conclusions}

We have reported the first 1,3-DC between azomethine ylides and 1,2-diaza-1,3-dienes (DDs). Two main classes of products can be obtained: 1,2,4-triazepines, and pyrrolidines by means of $[3+4]$ or [3+2] cycloadditions, respectively. We have demonstrated as the preference of the $[3+4]$ cycloaddition is controlled by the presence in N-EWG-DDs 1a-f of an electronwithdrawing group bound directly to the azo-moiety able to stabilize the anionic intermediate. On the contrary, under the same conditions the reactions of $\mathrm{N}$-phenyl DDs lacking of electron withdrawing moiety on the nitrogen in position 1 of the azo-ene system gave the [3+2] cycloaddition product. Furthermore, the $[3+2]$ cycloadditions show the same regioselectivity of the attack of the negative charge of the dipole displayed for the reactions involving nitrones, ${ }^{[20]}$ but with the opposite trend in respect to the [3+4] cycloaddition.

The normal endo-approach of DDs 1 was confirmed in the [3+2] processes finding two ester and methyl groups in a cisarrangement. Considering the operational simplicity and that the obtained products represent interesting scaffolds deployed with a variety of functional groups, a convenient and practical synthetic methodology has been developed.

\section{Experimental Section}

General information. All the commercially available reagents and solvents were used without further purification. 1,2-Diaza-1,3-dienes 1a-h were synthesized as a mixture of $E / Z$ isomers as previously reported. ${ }^{35}$ Sarcosine $\mathbf{2 a}, \quad N$-benzyl glycine ethyl ester $\mathbf{6 a}$ or ethyl pipecolinate $\mathbf{6 b}$ and paraformaldehyde $\mathbf{3 a}$ are commercial materials and were used without further purification. Chromatographic purification of compounds was carried out on silica gel $(60-200 \mu \mathrm{m})$. TLC analysis was performed on pre-loaded $(0.25 \mathrm{~mm})$ glass supported silica gel plates (Kieselgel 60); compounds were visualized by exposure to UV light and by dipping the plates in $1 \% \mathrm{Ce}\left(\mathrm{SO}_{4}\right) \cdot 4 \mathrm{H}_{2} \mathrm{O}, 2.5 \%\left(\mathrm{NH}_{4}\right)_{6} \mathrm{Mo}_{7} \mathrm{O}_{24} \cdot 4 \mathrm{H}_{2} \mathrm{O}$ in $10 \%$ sulphuric acid followed by heating on a hot plate. All ${ }^{1} \mathrm{H}$ NMR and ${ }^{13} \mathrm{C}$ NMR spectra were recorded at 400 and $100.56 \mathrm{MHz}$, respectively. Proton and carbon spectra were referenced internally to solvent signals, using values of $\delta=2.50 \mathrm{ppm}$ for proton (middle peak) and $\delta=39.50 \mathrm{ppm}$ for carbon (middle peak) in DMSO- $d_{6}$ and $\delta=7.27$ ppm for proton and $\delta=77.00 \mathrm{ppm}$ for carbon (middle peak) in $\mathrm{CDCl}_{3}$. The following abbreviations are used to describe peak patterns where appropriate: $\mathrm{s}=$ singlet, $\mathrm{d}=$ doublet, $\mathrm{t}=$ triplet $\mathrm{q}=$ quartet, $\mathrm{sex}=$ sextet, $\mathrm{m}$ $=$ multiplet and $\mathrm{br}=$ broad signal. All coupling constants $(J)$ are given in Hz. FT-IR spectra were obtained as Nujol mulls. Mass spectra were recorded in the $\mathrm{EI}$ mode $(70 \mathrm{eV})$. Melting points were determined in open capillary tubes and are uncorrected

General procedure for the synthesis of 3,4,5,6-tetrahydro-2H-1,2,4 triazepine-2,6-dicarboxylate 4a-f. DDs 1a-f $(2.0 \mathrm{mmol})$, sarcosine $2 \mathrm{a}$ $(90 \mathrm{mg}, 1.0 \mathrm{mmol})$, and paraformaldehyde $3 \mathbf{a}(60 \mathrm{mg}, 2.0 \mathrm{mmol})$ were dissolved in toluene $(5 \mathrm{~mL})$. The reactions were refluxed for $5.0-7.0 \mathrm{~h}$. Then, the solvent was evaporated under reduced pressure and the crude mixture was chromatographed on silica gel (ethyl acetate : cyclohexane) obtaining pure 3,4,5,6-tetrahydro- $2 \mathrm{H}$-1,2,4-triazepine-2,6-dicarboxylates 4a-f.

2-Tert-butyl 6-methyl 4,7-dimethyl-3,4,5,6-tetrahydro-2H-1,2,4triazepine-2,6-dicarboxylate 4a: Pale yellow oil, $185 \mathrm{mg}, 65 \%$; IR $\mathrm{v}_{\max }$ 1758, $1713 \mathrm{~cm}^{-1} ;{ }^{1} \mathrm{H}-\mathrm{NMR} \delta: 1.50\left(\mathrm{~s}, 9 \mathrm{H}, \mathrm{C}\left(\mathrm{CH}_{3}\right)_{3}\right), 2.07\left(\mathrm{~s}, 3 \mathrm{H}, \mathrm{CH}_{3}\right)$, $2.42\left(\mathrm{~s}, 3 \mathrm{H}, \mathrm{NCH}_{3}\right), 2.85\left(\mathrm{dd}, 1 \mathrm{H}, \mathrm{J}=13.2 \mathrm{~Hz}, \mathrm{~J}=2.4 \mathrm{~Hz}, \mathrm{CHCH}_{2} \mathrm{NCH}_{3}\right.$ )
3.07 (dd, $\left.1 \mathrm{H}, \mathrm{J}=13.2 \mathrm{~Hz}, \mathrm{~J}=7.6 \mathrm{~Hz}, \mathrm{CHCH}_{2} \mathrm{NCH}_{3}\right), 3.73-3.79(\mathrm{~m}, 1 \mathrm{H}$, $\left.\mathrm{CHCH}_{2} \mathrm{NCH}_{3}\right), 3.75(\mathrm{~s}, 3 \mathrm{H}), 4.23\left(\mathrm{~d}, 1 \mathrm{H}, \mathrm{J}=14.0 \mathrm{~Hz}, \mathrm{NCH}_{2} \mathrm{~N}\right), 4.72(\mathrm{~d}$ $\left.1 \mathrm{H}, \mathrm{J}=14.0 \mathrm{~Hz}, \mathrm{NCH}_{2} \mathrm{~N}\right) ;{ }^{13} \mathrm{C}-\mathrm{NMR} \delta: 23.6(\mathrm{q}), 28.1$ (q), 41.2 (q), 49.0 (t), $51.7(\mathrm{~d}), 52.4(\mathrm{q}), 69.6(\mathrm{t}), 81.6(\mathrm{~s}), 158.9(\mathrm{~s}), 170.9(\mathrm{~s}), 174.8(\mathrm{~s}) ; \mathrm{MS}$ (EI) $\mathrm{m} / \mathrm{z}(\%): 285\left(\mathrm{M}^{+}, 1 \%\right), 270$ (3), 254 (2), 226 (2), 212 (7), 169 (10), 153 (18), 110 (9); anal. calcd. for $\mathrm{C}_{13} \mathrm{H}_{23} \mathrm{~N}_{3} \mathrm{O}_{4}$ (285.3395): C 54.72, H 8.12, N 14.73; found: C 54.59, H 8.08, N 14.87 .

2-Tert-butyl 6-ethyl 4,7-dimethyl-3,4,5,6-tetrahydro-2H-1,2,4 triazepine-2,6-dicarboxylate 4b: Pale yellow oil, $161 \mathrm{mg}, 54 \%$; IR $\mathrm{V}_{\max }$ : 1758, $1695 \mathrm{~cm}^{-1}$; ${ }^{1} \mathrm{H}-\mathrm{NMR}\left(\mathrm{CDCl}_{3}\right) \delta: 1.28\left(\mathrm{t}, 3 \mathrm{H}, \mathrm{J}=7.2 \mathrm{~Hz}, \mathrm{OCH}_{2} \mathrm{CH}_{3}\right)$, $1.50\left(\mathrm{~s}, 9 \mathrm{H}, \mathrm{C}\left(\mathrm{CH}_{3}\right)_{3}\right), 2.08\left(\mathrm{~s}, 3 \mathrm{H}, \mathrm{CH}_{3}\right), 2.42\left(\mathrm{~s}, 3 \mathrm{H}, \mathrm{NCH}_{3}\right), 2.84(\mathrm{dd}$ $\left.1 \mathrm{H}, \mathrm{J}=13.2 \mathrm{~Hz}, \mathrm{~J}=2.4 \mathrm{~Hz}, \mathrm{CHCH}_{2} \mathrm{NCH}_{3}\right), 3.05(\mathrm{dd}, 1 \mathrm{H}, \mathrm{J}=13.2 \mathrm{~Hz}, \mathrm{~J}$ $\left.=7.6 \mathrm{~Hz}, \mathrm{CHCH}_{2} \mathrm{NCH}_{3}\right), 3.75(\mathrm{dd}, 1 \mathrm{H}, \mathrm{J}=7.6 \mathrm{~Hz}, \mathrm{~J}=2.0 \mathrm{~Hz}$, $\left.\mathrm{CHCH}_{2} \mathrm{NCH}_{3}\right), 4.17-4.25\left(\mathrm{~m}, 3 \mathrm{H}, \mathrm{OCH}_{2} \mathrm{CH}_{3}, \mathrm{NCH}_{2} \mathrm{~N}\right), 4.73(\mathrm{~d}, 1 \mathrm{H}, \mathrm{J}=$ $\left.14.0 \mathrm{~Hz}, \mathrm{NCH}_{2} \mathrm{~N}\right) ;{ }^{13} \mathrm{C}-\mathrm{NMR} \delta$ : 14.0 (q), 23.6 (q), 28.15 (q), $41.2(\mathrm{q}), 49.1$ $(\mathrm{t}), 51.8(\mathrm{~d}), 61.4(\mathrm{t}), 69.8(\mathrm{t}), 81.4(\mathrm{~s}), 154.4(\mathrm{~s}), 159.1(\mathrm{~s}), 170.4(\mathrm{~s}) ;$ MS (EI) $\mathrm{m} / \mathrm{z}(\%): 299\left(\mathrm{M}^{+}, 1 \%\right), 254$ (7), 241 (30), 225 (18), 198 (28), 153 (10), 125 (38); anal. calcd. for $\mathrm{C}_{14} \mathrm{H}_{25} \mathrm{~N}_{3} \mathrm{O}_{4}$ (299.3661): C 56.17, H 8.42, N 14.04; found: C 56.29, H 8.45, N 13.92

2-Tert-butyl 6-methyl 7-ethyl-4-methyl-3,4,5,6-tetrahydro-2H-1,2,4triazepine-2,6-dicarboxylate 4c: Pale yellow oil, $117 \mathrm{mg}, 39 \%$; IR $\mathrm{V}_{\max }$ 1748, $1697 \mathrm{~cm}^{-1},{ }^{1} \mathrm{H}-\mathrm{NMR} \delta: 1.14\left(\mathrm{t}, 3 \mathrm{H}, \mathrm{J}=7.6 \mathrm{~Hz}, \mathrm{CH}_{2} \mathrm{CH}_{3}\right), 1.50(\mathrm{~s}$, $\left.9 \mathrm{H}, \mathrm{C}\left(\mathrm{CH}_{3}\right)_{3}\right), 2.29-2.45\left(\mathrm{~m}, 2 \mathrm{H}, \mathrm{CH}_{2} \mathrm{CH}_{3}\right), 2.39\left(\mathrm{~s}, 3 \mathrm{H}, \mathrm{NCH}_{3}\right), 2.80$ (dd $\left.1 \mathrm{H}, \mathrm{J}=12.8 \mathrm{~Hz}, \mathrm{~J}=2.4 \mathrm{~Hz}, \mathrm{CHCH}_{2} \mathrm{NCH}_{3}\right), 3.12(\mathrm{dd}, 1 \mathrm{H}, \mathrm{J}=12.8 \mathrm{~Hz}, \mathrm{~J}$ $\left.=6.8 \mathrm{~Hz}, \mathrm{CHCH}_{2} \mathrm{NCH}_{3}\right), 3.72$ (dd, $1 \mathrm{H}, \mathrm{J}=6.8 \mathrm{~Hz}, \mathrm{~J}=2.4 \mathrm{~Hz}$ $\left.\mathrm{CHCH}_{2} \mathrm{NCH}_{3}\right), 3.75\left(\mathrm{~s}, 3 \mathrm{H}, \mathrm{OCH}_{3}\right), 4.34\left(\mathrm{~d}, 1 \mathrm{H}, \mathrm{J}=14.0 \mathrm{~Hz}, \mathrm{NCH}_{2} \mathrm{~N}\right)$ $4.57(\mathrm{~d}, 1 \mathrm{H}, \mathrm{J}=14.0 \mathrm{~Hz}) ;{ }^{13} \mathrm{C}-\mathrm{NMR} \delta: 11.0(\mathrm{q}), 28.2(\mathrm{q}), 30.8(\mathrm{t}), 41.6(\mathrm{q})$ $48.6(\mathrm{t}), 52.3(\mathrm{~d}), 52.5(\mathrm{q}), 69.6(\mathrm{t}), 81.3(\mathrm{~s}), 154.4(\mathrm{~s}), 162.4(\mathrm{~s}), 171.0$ (s); MS (El) m/z (\%): $299\left(\mathrm{M}^{+}, 2 \%\right), 268$ (2), 226 (6), 198 (4), 183 (10) 167 (17); anal. calcd. for $\mathrm{C}_{14} \mathrm{H}_{25} \mathrm{~N}_{3} \mathrm{O}_{4}$ (299.3661): C 56.17, $\mathrm{H} 8.42, \mathrm{~N}$ 14.04; found: C 56.06, H 8.39, N 14.27 .

2-Tert-butyl 6-methyl 4-methyl-7-propyl- 3,4,5,6-tetrahydro-2H-1,2,4 triazepine-2,6-dicarboxylate 4d: Pale yellow oil, $100 \mathrm{mg}, 32 \%$; IR $\mathrm{V}_{\max }$ 1750, $1704 \mathrm{~cm}^{-1}$; ${ }^{1} \mathrm{H}$-NMR $\delta: 0.93\left(\mathrm{t}, 3 \mathrm{H}, \mathrm{J}=7.2 \mathrm{~Hz}, \mathrm{CH}_{2} \mathrm{CH}_{2} \mathrm{CH}_{3}\right), 1.48$ $\left(\mathrm{s}, 9 \mathrm{H}, \mathrm{C}\left(\mathrm{CH}_{3}\right)_{3}\right), 1.59\left(\mathrm{sex}, 2 \mathrm{H}, \mathrm{CH}_{2} \mathrm{CH}_{2} \mathrm{CH}_{3}\right), 2.22-2.35(\mathrm{~m}, 2 \mathrm{H}$, $\left.\mathrm{CH}_{2} \mathrm{CH}_{2} \mathrm{CH}_{3}\right) 2.40\left(\mathrm{~s}, 3 \mathrm{H}, \mathrm{NCH}_{3}\right), 2.77(\mathrm{dd}, 1 \mathrm{H}, \mathrm{J}=12.8 \mathrm{~Hz}, \mathrm{~J}=2.4 \mathrm{~Hz}$ $\left.\mathrm{CHCH}_{2} \mathrm{NCH}_{3}\right), 3.10\left(\mathrm{dd}, 1 \mathrm{H}, J=12.8 \mathrm{~Hz}, \mathrm{~J}=6.8 \mathrm{~Hz}, \mathrm{CHCH}_{2} \mathrm{NCH}_{3}\right.$ ), $3.70\left(\mathrm{dd}, 1 \mathrm{H}, \mathrm{J}=6.8 \mathrm{~Hz}, \mathrm{~J}=2.4 \mathrm{~Hz}, \mathrm{CHCH}_{2} \mathrm{NCH}_{3}\right), 3.73\left(\mathrm{~s}, 3 \mathrm{H}, \mathrm{OCH}_{3}\right)$ $4.32\left(\mathrm{~d}, 1 \mathrm{H}, \mathrm{J}=14.0 \mathrm{~Hz}, \mathrm{NCH}_{2} \mathrm{~N}\right), 4.52(\mathrm{~d}, 1 \mathrm{H}, \mathrm{J}=14.0 \mathrm{~Hz}$, $\left.\mathrm{NCH}_{2} \mathrm{~N}\right) ;{ }^{13} \mathrm{C}-\mathrm{NMR} \delta$ : $14.1(\mathrm{q}), 21.0(\mathrm{t}), 28.2(\mathrm{q}), 39.4(\mathrm{t}), 41.4(\mathrm{q}), 48.7(\mathrm{t})$, $52.2(\mathrm{q}), 52.4(\mathrm{~d}), 69.5(\mathrm{t}), 81.2(\mathrm{~s}), 161.9(\mathrm{~s}), 170.9(\mathrm{~s}), 171.1(\mathrm{~s}) ; \mathrm{MS}$ (EI) m/z (\%): 298 (2), 281 (3), 255 (4), 197 (21), 181 (18), 167 (31), 153 (24); anal. calcd. for $\mathrm{C}_{15} \mathrm{H}_{27} \mathrm{~N}_{3} \mathrm{O}_{4}$ (313.3927): C 57.49, $\mathrm{H} 8.68, \mathrm{~N} 13.41$ found: C 57.38, H 8.66, N 13.52

Tert-butyl 6-[(dimethylamino)carbonyl]-4,7-dimethyl-3,4,5,6 tetrahydro-2H-1,2,4-triazepine-2-dicarboxylate 4e: Pale yellow oil, 75 mg, 25\%;IR $v_{\max }: 1746,1707 \mathrm{~cm}^{-1} ;{ }^{1} \mathrm{H}-\mathrm{NMR} \delta: 1.50\left(\mathrm{~s}, 9 \mathrm{H}, \mathrm{C}\left(\mathrm{CH}_{3}\right)_{3}\right)$, $2.02\left(\mathrm{~s}, 3 \mathrm{H}, \mathrm{CH}_{3}\right), 2.45\left(\mathrm{~s}, 3 \mathrm{H}, \mathrm{NCH}_{3}\right), 2.79-2.95\left(\mathrm{~m}, 2 \mathrm{H}, \mathrm{CHCH}_{2} \mathrm{NCH}_{3}\right)$ $2.97\left(\mathrm{~s}, 3 \mathrm{H}, \mathrm{N}(\mathrm{Me})_{2}\right), 2.98\left(\mathrm{~s}, 3 \mathrm{H}, \mathrm{N}(\mathrm{Me})_{2}\right), 3.86(\mathrm{~d}, 1 \mathrm{H}, \mathrm{J}=13.6 \mathrm{~Hz}$, $\mathrm{NCH}_{2} \mathrm{~N}$ ), 4.21 (dd, $\left.1 \mathrm{H}, \mathrm{J}=9.2 \mathrm{~Hz}, \mathrm{~J}=2.0 \mathrm{~Hz}, \mathrm{CHCH}_{2} \mathrm{NCH}_{3}\right), 4.87(\mathrm{~d}, 1 \mathrm{H}$, $\left.\mathrm{J}=13.6 \mathrm{~Hz}, \mathrm{NCH}_{2} \mathrm{~N}\right) ;{ }^{13} \mathrm{C}-\mathrm{NMR} \delta: 21.6(\mathrm{q}), 28.2(\mathrm{q}), 35.5$ (q), 37.4 (q), $40.4(\mathrm{q}), 44.4(\mathrm{t}), 51.7(\mathrm{~d}), 69.6(\mathrm{t}), 81.4(\mathrm{~s}), 154.5(\mathrm{~s}), 166.0(\mathrm{~s}), 170.1$ (s); MS (El) m/z (\%): 298 (M+2\%), 241 (4), 225 (19), 197 (63), 153 (18), 125 (78); anal. calcd. for $\mathrm{C}_{16} \mathrm{H}_{26} \mathrm{~N}_{4} \mathrm{O}_{3}$ (298.3814): C 56.35, H 8.78, N 18.78; found: C 56.49, $\mathrm{H} 8.83, \mathrm{~N} 18.66$.

2-Benzyl 6-ethyl 4,7-dimethyl-3,4,5,6-tetrahydro-2H-1,2,4-triazepine2,6-dicarboxylate 4f: Pale yellow oil, $117 \mathrm{mg}, 39 \%$; IR $\mathrm{V}_{\max }$ : 1746, 1704 $\mathrm{cm}^{-1},{ }^{1} \mathrm{H}-N M R$ : $1.28\left(\mathrm{t}, 3 \mathrm{H}, \mathrm{J}=7.2 \mathrm{~Hz}, \mathrm{OCH}_{2} \mathrm{CH}_{3}\right), 2.11\left(\mathrm{~s}, 3 \mathrm{H}, \mathrm{CH}_{3}\right)$ $2.44\left(\mathrm{~s}, 3 \mathrm{H}, \mathrm{NCH}_{3}\right), 2.86\left(\mathrm{dd}, 1 \mathrm{H}, \mathrm{J}=13.2 \mathrm{~Hz}, \mathrm{~J}=2.4 \mathrm{~Hz}, \mathrm{CHCH}_{2} \mathrm{NCH}_{3}\right)$, 3.10 (dd, $\left.1 \mathrm{H}, \mathrm{J}=13.2 \mathrm{~Hz}, \mathrm{~J}=7.6 \mathrm{~Hz}, \mathrm{CHCH}_{2} \mathrm{NCH}_{3}\right), 3.79$ (dd, $1 \mathrm{H}, \mathrm{J}=$ $\left.7.6 \mathrm{~Hz}, \mathrm{~J}=2.4 \mathrm{~Hz}, \mathrm{CHCH}_{2} \mathrm{NCH}_{3}\right), 4.18-4.23\left(\mathrm{~m}, 2 \mathrm{H}, \mathrm{OCH}_{2} \mathrm{CH}_{3}\right), 4.31$ (d, $1 \mathrm{H}, \mathrm{J}=14.0 \mathrm{~Hz}), 4.81(\mathrm{~d}, 1 \mathrm{H}, \mathrm{J}=14.0 \mathrm{~Hz}), 5.26\left(\mathrm{~s}, 2 \mathrm{H}, \mathrm{OCH}_{2} \mathrm{Ph}\right), 7.30-$

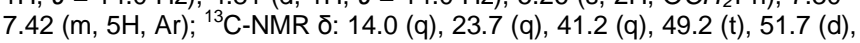
$61.5(\mathrm{t}), 68.0(\mathrm{t}), 69.9(\mathrm{t}), 128.1(\mathrm{~d}), 128.3(\mathrm{~d}), 128.4(\mathrm{~d}), 136.1(\mathrm{~s}), 160.5$ (s), 166.5 (s), 170.2 (s); MS (EI) m/z (\%): 287 (7), 260 (2), 167 (28), 149 (100), 123 (50); anal. calcd. for $\mathrm{C}_{17} \mathrm{H}_{23} \mathrm{~N}_{3} \mathrm{O}_{4}$ (333.3382): C 61.25, H 6.95, N 12.60; found: C 61.38, H 6.99, N 12.47 .

General procedure for the synthesis of 4- 
phenyldiazenyl)pyrrolidine-2,4-dicarboxylates

$7 a, b$, (phenyldiazenyl)hexahydroindolizine-2,8a(1H)-dicarboxylate $7 \mathrm{c}, \mathrm{d}$ Sarcosine $\mathbf{2 a}(90 \mathrm{mg}, 1.0 \mathrm{mmol})$, or $\mathrm{N}$-benzylglycine ethyl ester $\mathbf{6 a}$ (193 $\mathrm{mg}, 1.0 \mathrm{mmol})$, or ethyl pipecolinate $\mathbf{6 b}(157 \mathrm{mg}, 1.0 \mathrm{mmol})$, DDs $\mathbf{1 g}, \mathbf{h}$ $(2.0 \mathrm{mmol})$, and paraformaldehyde $3 \mathbf{a}(2.0 \mathrm{mmol})$ were dissolved in toluene $(5 \mathrm{~mL})$. The reactions were refluxed for 5.0-7.0. Then, the solvent was evaporated under reduced pressure and the crude mixture was chromatographed on silica gel (ethyl acetate : cyclohexane) obtaining 4 [phenyldiazenyl]pyrrolidine-3-carboxylates $\quad 5 \mathbf{a}, \mathbf{b}, \quad 3-(2-$ phenyldiazenyl)pyrrolidine-2,4-dicarboxylates $7 a, b$, 3- $(2-$ (phenyldiazenyl)hexahydroindolizine-2,8a(1H)-dicarboxylate $7 \mathbf{c}, \mathbf{d}$

Methyl 1,4-dimethyl-4-[phenyldiazenyl]pyrrolidine-3-carboxylate 5a Pale yellow oil, $157 \mathrm{mg}, 60 \%$; IR $\mathrm{v}_{\text {max }}: 1749 \mathrm{~cm}^{-1} ;{ }^{1} \mathrm{H}-\mathrm{NMR} \delta: 1.32(\mathrm{~s}, 3 \mathrm{H}$ $\left.\mathrm{CH}_{3}\right), 2.38\left(\mathrm{~s}, 3 \mathrm{H}, \mathrm{NCH}_{3}\right), 2.52\left(\mathrm{~d}, 1 \mathrm{H}, \mathrm{J}=10.0 \mathrm{~Hz}, \mathrm{CH}_{2} \mathrm{NCH}_{3}\right), 2.92$ (dd, $1 \mathrm{H}, \mathrm{J}=9.6 \mathrm{~Hz}, \mathrm{~J}=8.4 \mathrm{~Hz}, \mathrm{CHCH}_{2} \mathrm{NCH}_{3}$ ), 3.13 (dd, $1 \mathrm{H}, \mathrm{J}=8.8 \mathrm{~Hz}$, $\left.\mathrm{J}=8.4 \mathrm{~Hz}, \mathrm{CHCH}_{2} \mathrm{NCH}_{3}\right), 3.41\left(\mathrm{~d}, 1 \mathrm{H}, \mathrm{J}=10.0 \mathrm{~Hz}, \mathrm{CH}_{2} \mathrm{NCH}_{3}\right), 3.71(\mathrm{~s}$ $\left.3 \mathrm{H}, \mathrm{OCH}_{3}\right), 3.98\left(\mathrm{t}, 1 \mathrm{H}, \mathrm{J}=8.4 \mathrm{~Hz}, \mathrm{CHCH}_{2} \mathrm{NCH}_{3}\right), 7.40-7.48(\mathrm{~m}, 3 \mathrm{H}, \mathrm{Ar})$ 7.74 (dd, $2 \mathrm{H}, \mathrm{J}=7.6 \mathrm{~Hz}, \mathrm{~J}=1.2 \mathrm{~Hz}, \mathrm{Ar}$ ); ${ }^{13} \mathrm{C}-\mathrm{NMR} \delta: 19.8$ (q), 42.1 (q), 49.5 (d), $51.6(\mathrm{q}), 58.1(\mathrm{t}), 66.6(\mathrm{t}), 79.7$ (s), 122.5 (d), 128.8 (d), 130.6 (d), 151.4 (s), 173.4 (s); MS (El) m/z (\%): 261 (M 2\%), 183 (17), 169 (43), 156 (45), 149 (100); anal. calcd. for $\mathrm{C}_{14} \mathrm{H}_{19} \mathrm{~N}_{3} \mathrm{O}_{2}$ (261.3197): C 64.35, H 7.33, N 16.08; found: C 64.46, H 7.36, N 15.97.

Ethyl 1,4-dimethyl-4-[phenyldiazenyl]pyrrolidine-3-carboxylate $\mathbf{5 b}$ Pale yellow oil, $107 \mathrm{mg}$, 39\%; IR $\mathrm{v}_{\max }: 1734 \mathrm{~cm}^{-1} ;{ }^{1} \mathrm{H}-\mathrm{NMR} \delta: 1.26(\mathrm{t}, 3 \mathrm{H}$ $\left.\mathrm{J}=7.2 \mathrm{~Hz}, \mathrm{OCH}_{2} \mathrm{CH}_{3}\right), 1.34\left(\mathrm{~s}, 3 \mathrm{H}, \mathrm{CH}_{3}\right), 2.38\left(\mathrm{~s}, 3 \mathrm{H}, \mathrm{NCH}_{3}\right), 2.51$ (d, $\left.1 \mathrm{H}, \mathrm{J}=10.0 \mathrm{~Hz}, \mathrm{CH}_{2} \mathrm{NCH}_{3}\right), 2.91(\mathrm{dd}, 1 \mathrm{H}, \mathrm{J}=9.2 \mathrm{~Hz}, \mathrm{~J}=9.2 \mathrm{~Hz}$ $\mathrm{CHCH}_{2} \mathrm{NCH}_{3}$ ), 3.13 (dd, $1 \mathrm{H}, \mathrm{J}=8.8 \mathrm{~Hz}, \mathrm{~J}=8.8 \mathrm{~Hz}, \mathrm{CHCH}_{2} \mathrm{NCH}_{3}$ ), 3.41 (d, $\left.1 \mathrm{H}, \mathrm{J}=10.0 \mathrm{~Hz}, \mathrm{CH}_{2} \mathrm{NCH}_{3}\right), 3.98\left(\mathrm{t}, 1 \mathrm{H}, \mathrm{J}=8.4 \mathrm{~Hz}, \mathrm{CHCH}_{2} \mathrm{NCH}_{3}\right.$ ) 4.13-4.20 (m, 2H, OCH $\left.\mathrm{CH}_{3}\right), 7.40-7.48(\mathrm{~m}, 3 \mathrm{H}, \mathrm{Ar}), 7.73$ (dd, $2 \mathrm{H}, \mathrm{J}=$ $8.4 \mathrm{~Hz}, \mathrm{~J}=2.0 \mathrm{~Hz}, \mathrm{Ar}) ;{ }^{13} \mathrm{C}-\mathrm{NMR} \delta: 14.3$ (q), $19.8(\mathrm{q}), 42.2(\mathrm{q}), 49.7$ (d) $58.2(\mathrm{t}), 60.5(\mathrm{t}), 66.9(\mathrm{t}), 79.7(\mathrm{~s}), 122.5$ (d), 128.8 (d), 130.5 (d), 151.5 (s), 172.9 (s); MS (EI) m/z (\%): $275\left(\mathrm{M}^{+}\right.$5\%), 260 (4), 231 (10), 183 (90), 170 (100); anal. calcd. for $\mathrm{C}_{15} \mathrm{H}_{21} \mathrm{~N}_{3} \mathrm{O}_{2}$ (275.3463): $\mathrm{C} 65.43, \mathrm{H} 7.69, \mathrm{~N}$ 15.26; found: C 65.31, H 7.65, N 15.36.

2-Ethyl 4-methyl 1-benzyl-3-methyl-3-(2-phenyldiazenyl)pyrrolidine2,4-dicarboxylate $7 \mathrm{a}:{ }^{36}$ mixture of diastereoisomers Pale yellow oil $205 \mathrm{mg}$ 50\%; IR $\mathrm{v}_{\mathrm{max}}$ : $1755 \mathrm{~cm}^{-1}$. ${ }^{1} \mathrm{H}-\mathrm{NMR}(\mathrm{dr}$ 59:41, * denotes minor diasteoisomer signals) $\delta: 1.15^{\star}\left(\mathrm{t}, 3 \mathrm{H}, \mathrm{J}=7.2 \mathrm{~Hz}, \mathrm{OCH}_{2} \mathrm{CH}_{3}\right), 1.19(\mathrm{t}, 3 \mathrm{H}$ $\left.\mathrm{J}=7.2 \mathrm{~Hz}, \mathrm{OCH}_{2} \mathrm{CH}_{3}\right), 1.39\left(\mathrm{~s}, 3 \mathrm{H}, \mathrm{CH}_{3}\right), 1.49^{*}\left(\mathrm{~s}, 3 \mathrm{H}, \mathrm{CH}_{3}\right), 2.97(\mathrm{t}, 1 \mathrm{H}$ $\mathrm{J}=9.6 \mathrm{~Hz}, \mathrm{CHCO}_{2} \mathrm{Me}$ ), 3.02* (t, $1 \mathrm{H}, \mathrm{J}=9.6 \mathrm{~Hz}, \mathrm{CHCO}_{2} \mathrm{Me}$ ), 3.57* (s, $\left.2 \mathrm{H}, \mathrm{NCH}_{2} \mathrm{Ar}\right), 3.63\left(\mathrm{~s}, 3 \mathrm{H}, \mathrm{OCH}_{3}\right), 3.65^{\star}\left(\mathrm{s}, 3 \mathrm{H}, \mathrm{OCH}_{3}\right), 3.63-3.73(\mathrm{~m}, 2 \mathrm{H}$ $\left.\mathrm{NCH}_{2} \mathrm{Ar}\right)$, 3.89-3.96 (m, $\left.1 \mathrm{H}, \mathrm{CH}_{2} \mathrm{~N}\right)$, 4.03-4.22 (m, $4 \mathrm{H}, \mathrm{OCH}_{2} \mathrm{CH}_{3}, \mathrm{CH}_{2} \mathrm{~N}$ $\left.\mathrm{CHCO}_{2} \mathrm{Et}\right), 7.26-7.39(\mathrm{~m}, 5 \mathrm{H}, \mathrm{Ar}), 7.44-7.52(\mathrm{~m}, 3 \mathrm{H}, \mathrm{Ar}), 7.68-7.74(\mathrm{~m}$ $2 \mathrm{H}, \mathrm{Ar})$.

2-Ethyl 4-methyl 1-benzyl-3-methyl-3-(2-phenyldiazenyl)pyrrolidine2,4-dicarboxylate 7a: one pure diastereoisomer IR $\mathrm{V}_{\max }: 1755 \mathrm{~cm}$ ${ }^{1}$; ${ }^{1} \mathrm{H}-\mathrm{NMR} \delta: 1.19\left(\mathrm{t}, 3 \mathrm{H}, \mathrm{J}=7.2 \mathrm{~Hz}, \mathrm{OCH}_{2} \mathrm{CH}_{3}\right), 1.38\left(\mathrm{~s}, 3 \mathrm{H}, \mathrm{CH}_{3}\right), 2.96$ $\left(\mathrm{t}, 1 \mathrm{H}, \mathrm{J}=9.6 \mathrm{~Hz}, \mathrm{CHCO}_{2} \mathrm{Me}\right), 3.63\left(\mathrm{~s}, 3 \mathrm{H}, \mathrm{OCH}_{3}\right), 3.63-3.73(\mathrm{~m}, 2 \mathrm{H}$ $\mathrm{NCH}_{2} \mathrm{Ar}$ ), 3.92 (dd, $\left.1 \mathrm{H}, \mathrm{J}=9.2 \mathrm{~Hz}, \mathrm{~J}=7.4 \mathrm{~Hz} \mathrm{CH}{ }_{2} \mathrm{~N}\right), 4.03-4.23(\mathrm{~m}, 4 \mathrm{H}$ $\left.\mathrm{OCH}_{2} \mathrm{CH}_{3}, \mathrm{CH}_{2} \mathrm{~N}, \mathrm{CHCO}_{2} \mathrm{Et}\right), 7.26-7.33(\mathrm{~m}, 5 \mathrm{H}, \mathrm{Ar}), 7.43-7.52(\mathrm{~m}, 3 \mathrm{H}$, $\mathrm{Ar}), 7.72$ (dd, $2 \mathrm{H}, \mathrm{J}=8.0 \mathrm{~Hz}, \mathrm{~J}=1.6 .2 \mathrm{~Hz}, \mathrm{Ar}$ ); ${ }^{13} \mathrm{C}$-NMR $\delta: 14.2$ (q), 16.0 (q), $49.1(\mathrm{t}), 51.7(\mathrm{~d}), 52.4(\mathrm{q}), 57.2(\mathrm{t}), 60.5(\mathrm{t}), 72.0(\mathrm{~d}), 80.6(\mathrm{~s}), 122.3$ (d) , 127.1 (s), 128.2 (d), 128.8 (d), 129.0 (d), 130.6 (d), 151.6 (s), 170.7 (s), 171.6 (s); MS (EI) m/z (\%): 303 (15), 244 (20), 231 (7), 217 (5), 123 (34); anal. calcd. for $\mathrm{C}_{23} \mathrm{H}_{27} \mathrm{~N}_{3} \mathrm{O}_{4}$ (409.4873): C 67.46, $\mathrm{H}$ 6.65, N 10.26; found: $\mathrm{C} 67.56, \mathrm{H} 6.67, \mathrm{~N} 10.14$

Diethyl 1-benzyl-3-methyl-3-(2-phenyldiazenyl)pyrrolidine-2,4dicarboxylate $\mathbf{7 b}:{ }^{37}$ mixture of diastereoisomers Pale yellow oil, 123 mg, 29\%; IR $v_{\max }: 1742,1752 \mathrm{~cm}^{-1} ;{ }^{1} \mathrm{H}-\mathrm{NMR}(\mathrm{dr}$ 65:35, * denotes minor diasteoisomer signals) $\delta$ : $1.15^{\star}\left(\mathrm{t}, 3 \mathrm{H}, \mathrm{J}=7.2 \mathrm{~Hz}, \mathrm{OCH}_{2} \mathrm{CH}_{3}\right), 1.16(\mathrm{t}, 3 \mathrm{H}$ $\left.\mathrm{J}=6.8 \mathrm{~Hz}, \mathrm{OCH}_{2} \mathrm{CH}_{3}\right), 1.18\left(\mathrm{t}, 3 \mathrm{H}, \mathrm{J}=7.2 \mathrm{~Hz}, \mathrm{OCH}_{2} \mathrm{CH}_{3}\right), 1.21^{*}(\mathrm{t}, 3 \mathrm{H}$, $\left.\mathrm{J}=7.2 \mathrm{~Hz}, \mathrm{OCH}_{2} \mathrm{CH}_{3}\right), 1.40\left(\mathrm{~s}, 3 \mathrm{H}, \mathrm{CH}_{3}\right), 1.50^{*}\left(\mathrm{~s}, 3 \mathrm{H}, \mathrm{CH}_{3}\right), 2.96(\mathrm{t}, 1 \mathrm{H}$ $\left.\mathrm{J}=10.0 \mathrm{~Hz}, \mathrm{CHCO}_{2} \mathrm{Me}\right), 3.03^{*}\left(\mathrm{t}, 1 \mathrm{H}, \mathrm{J}=9.6 \mathrm{~Hz}, \mathrm{CHCO}_{2} \mathrm{Me}\right), 3.63-3.72$ $\left(\mathrm{m}, 2 \mathrm{H}, \mathrm{NCH}_{2} \mathrm{Ar}\right), 3.86-3.91\left(\mathrm{~m}, 1 \mathrm{H}, \mathrm{CH}_{2} \mathrm{~N}\right), 4.02-4.22(\mathrm{~m}, 6 \mathrm{H}, 2$ $\left.\mathrm{OCH}_{2} \mathrm{CH}_{3}, \mathrm{CH}_{2} \mathrm{~N}, \mathrm{CHCO}_{2} \mathrm{Et}\right), 7.24-7.41(\mathrm{~m}, 5 \mathrm{H}, \mathrm{Ar}), 7.44-7.52(\mathrm{~m}, 3 \mathrm{H}$, $\mathrm{Ar})$, 7.67-7.73 (m, 2H, Ar); ${ }^{13} \mathrm{C}-\mathrm{NMR} \delta: 14.1$ (q), 14.2 (q), 15.7 (q), 19.8 (q), $48.2(\mathrm{q}), 49.5(\mathrm{t}), 52.3(\mathrm{~d}), 53.1(\mathrm{~d}), 57.4(\mathrm{t}), 57,6(\mathrm{t}), 60.4(\mathrm{t}), 60.5(\mathrm{t})$ $60.6(\mathrm{t}), 72.1$ (s), 75.0 (d), 80.4 (s), 122.2 (d) , 122.3 (d), 122.5 (d), 127.1 (s), 127.2 (s), 128.1 (d), 128.2 (d), 128.8 (d), 128.8 (d), 128.9 (d), 129.2 (d), 130.5 (d), 130.7 (d), 151.4 (s), 151.7 (s), 170.3 (s), 170.9 (s), 172.1 (s)172.8 (s); MS (El) m/z (\%): 318 (4), 245 (5), 244 (16), 167 (17), 123 (46); anal. calcd. for $\mathrm{C}_{24} \mathrm{H}_{29} \mathrm{~N}_{3} \mathrm{O}_{4}$ (423.5049): C 68.06, H 6.90, N 9.92; found: C 67.95, H 6.87, N 10.03 .

8a-Ethyl 2-methyl 1-methyl-1-(phenyldiazenyl)hexahydroindolizine2,8a(1H)-dicarboxylate 7c: Pale yellow oil, $149 \mathrm{mg}, 40 \%$; IR $\mathrm{v}_{\max }$ : 1754, $1752 \mathrm{~cm}^{-1}$; ${ }^{1} \mathrm{H}$-NMR $\delta: 1.23\left(\mathrm{t}, 3 \mathrm{H}, \mathrm{J}=7.2 \mathrm{~Hz}, \mathrm{OCH}_{2} \mathrm{CH}_{3}\right), 1.30(\mathrm{~s}, 3 \mathrm{H}$ $\left.\mathrm{CH}_{3}\right)$, 1.58-1.81 (m, 4H, $\left.\mathrm{CH}_{2} \mathrm{CH}_{2}\right), 1.97-2.06\left(\mathrm{~m}, 2 \mathrm{H}, \mathrm{CH}_{2} \mathrm{CH}_{2}\right), 2.91$ (dd, $1 \mathrm{H}, \mathrm{J}=13.6 \mathrm{~Hz}, \mathrm{~J}=4.4 \mathrm{~Hz}, \mathrm{NCH}_{2} \mathrm{CH}_{2}$ ), $3.13(\mathrm{dt}, 1 \mathrm{H}, \mathrm{J}=13.2 \mathrm{~Hz}, \mathrm{~J}$ $\left.=3.6 \mathrm{~Hz}, \mathrm{NCH}_{2} \mathrm{CH}_{2}\right), 3.36\left(\mathrm{dd}, 1 \mathrm{H}, \mathrm{J}=10.0 \mathrm{~Hz}, \mathrm{~J}=9.6 \mathrm{~Hz}, \mathrm{CHCO}_{2} \mathrm{Me}\right)$ $3.59\left(\mathrm{~s}, 3 \mathrm{H}, \mathrm{CO}_{2} \mathrm{CH}_{3}\right), 3.81(\mathrm{dd}, 1 \mathrm{H}, \mathrm{J}=9.2 \mathrm{~Hz}, \mathrm{~J}=7.2 \mathrm{~Hz}$ $\left.\mathrm{CH}_{2} \mathrm{CHCO}_{2} \mathrm{Me}\right), 4.13-4.27\left(\mathrm{~m}, 3 \mathrm{H}, \mathrm{OCH}_{2} \mathrm{CH}_{3}, \mathrm{CH}_{2} \mathrm{CHCO}_{2} \mathrm{Me}\right), 7.43$ $7.49(\mathrm{~m}, 3 \mathrm{H}, \mathrm{Ar}), 7.70(\mathrm{dd}, 2 \mathrm{H}, \mathrm{J}=8.0 \mathrm{~Hz}, \mathrm{~J}=1.6 \mathrm{~Hz}, \mathrm{Ar}) ;{ }^{13} \mathrm{C}-\mathrm{NMR} \delta$ $14.2(\mathrm{q}), 16.9(\mathrm{q}), 20.2(\mathrm{t}), 21.8(\mathrm{t}), 27.1(\mathrm{t}), 45.6(\mathrm{t}), 46.6(\mathrm{~d}), 50.2(\mathrm{t})$ 51.5 (q), 60.6 (t), 75.9 (s), 81.1 (s), 122.4 (d) , 128.9 (d), 130.4 (d), 151.8 (s), 172.1 (s), 172.3 (s); MS (El) m/z (\%): 300 (4), 195 (25), 164 (14), 136 (40); anal. calcd. for $\mathrm{C}_{20} \mathrm{H}_{27} \mathrm{~N}_{3} \mathrm{O}_{4}$ (373.4462): C 64.32, H 7.29, N 11.25; found: C 64.45, H 7.34, N 11.17.

Diethyl 1-methyl-1-(phenyldiazenyl)hexahydroindolizine-2,8a(1H) dicarboxylate 7d: Pale yellow oil, $174 \mathrm{mg}, 45 \%$; IR $\mathrm{V}_{\max }: 1743,1736 \mathrm{~cm}$ 1. ${ }^{1} \mathrm{H}-\mathrm{NMR} \delta: 1.13\left(\mathrm{t}, 3 \mathrm{H}, \mathrm{J}=7.2 \mathrm{~Hz}, \mathrm{OCH}_{2} \mathrm{CH}_{3}\right), 1.20(\mathrm{t}, 3 \mathrm{H}, \mathrm{J}=7.2 \mathrm{~Hz}$, $\left.\mathrm{OCH}_{2} \mathrm{CH}_{3}\right), 1.31\left(\mathrm{~s}, 3 \mathrm{H}, \mathrm{CH}_{3}\right), 1.64-1.89\left(\mathrm{~m}, 4 \mathrm{H}, \mathrm{CH}_{2} \mathrm{CH}_{2}\right), 2.08(\mathrm{~d}, 1 \mathrm{H}$ $\left.\mathrm{J}=13.2 \mathrm{~Hz}, \mathrm{CH}_{2} \mathrm{CH}_{2}\right), 2.92\left(\mathrm{~d}, 1 \mathrm{H}, \mathrm{J}=10.8 \mathrm{~Hz}, \mathrm{CH}_{2} \mathrm{CH}_{2}\right), 3.17(\mathrm{dt}, 1 \mathrm{H}$, $\left.\mathrm{J}=13.2 \mathrm{~Hz}, \mathrm{~J}=3.2 \mathrm{~Hz}, \quad \mathrm{NCH}_{2} \mathrm{CH}_{2}\right), 3.37(\mathrm{t}, 1 \mathrm{H}, \mathrm{J}=10.0 \mathrm{~Hz}$ $\left.\mathrm{NCH}_{2} \mathrm{CH}_{2}\right), \quad 3.81-3.85\left(\mathrm{~m}, 1 \mathrm{H}, \quad \mathrm{CHCO}_{2} \mathrm{Et}\right), \quad 4.00-4.26(\mathrm{~m}, 6 \mathrm{H}, 2$ $\mathrm{OCH}_{2} \mathrm{CH}_{3}, \mathrm{CH}_{2} \mathrm{CHCO}_{2} \mathrm{Me}$ ), 7.42-7.50 (m, 3H, Ar), 7.69 (dd, $2 \mathrm{H}, \mathrm{J}=8.0$

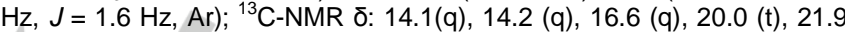
$(\mathrm{t}), 27.2(\mathrm{t}), 45.7(\mathrm{~d}), 46.8(\mathrm{t}), 50.0(\mathrm{t}), 60.5(\mathrm{t}), 60.7(\mathrm{t}), 76.1(\mathrm{~s}), 81.0(\mathrm{~s})$ 122.4 (d), 128.9 (d), 130.4 (d), 152.0 (s), 171.7 (s), 172.2 (s); MS (El) m/z (\%): 315 (3), 314 (13), 287 (7), 209 (42), 179 (12), 164 (14), 136 (82); anal. calcd. for $\mathrm{C}_{21} \mathrm{H}_{29} \mathrm{~N}_{3} \mathrm{O}_{4}$ (387.4728): C 65.09, $\mathrm{H} 7.54, \mathrm{~N} 10.84$ found: C 65.22, H 7.47, N 10.73.

\section{Acknowledgements}

The Spanish authors thanks the Spanish Ministerio de Ciencia e Innovación (MICINN) (projects CTQ2010-20387, and Consolider Ingenio 2010, CSD2007-00006), the Spanish Ministerio de Economía y Competitividad (MINECO) (projects CTQ201343446-P, and CTQ2014-51912-REDC), FEDER, the Generalitat Valenciana (PROMETEO 2009/039 and PROMETEOII/ 2014/017), and the University of Alicante, for the financial support. The Italians authors gratefully acknowledge the financial support from the University of Urbino "Carlo Bo", and the PhD Programs of Ministry of dell'Universita', dell'Istruzione e della Ricerca of Italy.

Keywords: Azomethine ylides • Cycloaddition • 1,2-Diaza-1,3diene $\bullet$ 1,2,4-Triazepine $\bullet$ Pyrrolidine 
Entry for the Table of Contents (Please choose one layout)

Layout 1:

\section{FULL PAPER}

Text for Table of Contents

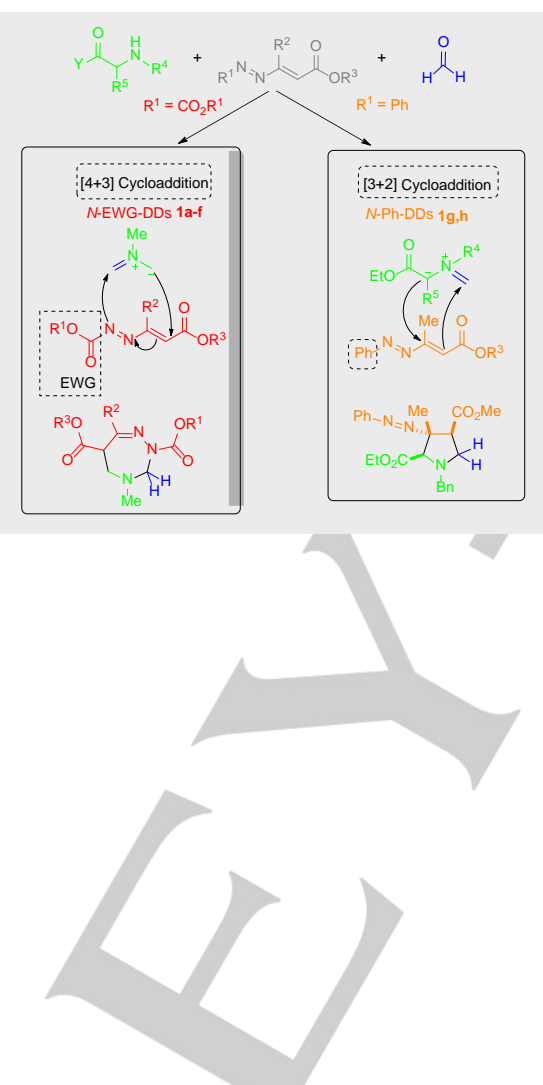

[4+3] vs [3+2] cycloadditions

Serena Mantenuto, Alberto Cayuelas, Gianfranco Favi, Orazio A. Attanasi, Fabio Mantellini, ${ }^{\star}$ Carmen Nájera, and José M. Sansano*

Page No. - Page No.

Reactivity of 1,2-diaza-1,3-dienes with

azomethine ylides: $[3+4]$ versus [3+2]

cycloadditions

[1] J. S. Clovis; A. Eckell, R. Huisgen, R. Sustmann, Chem. Ber. 1967, 100, 60-70.

[2] a) Synthetic Applications of 1,3-Dipolar Cycloaddition Chemistry Toward Heterocycles and Natural Products, A. Padwa, W. H. Pearson, Eds., John Wiley \& Sons: New Jersey, 2003; b) C. Nájera, J. M. Sansano, Curr. Org. Chem. 2003, 7, 1105-1150; c) W. Eberbach, In Sci. Synth.,Houben-Weyl Methods of Molecular Transformations; A.Padwa, D. Bellus, Eds. ThiemeVerlag: Stuttgart, 2004; Vol. 27, chp. 11, pp 441-498; d) I. Coldham, R. Hufton, Chem. Rev. 2005, 105, 2765-2810; e) V. Nair, T. D. Suja, Tetrahedron 2007, 63, 12247-12275; f) A. Padwa, S. K. Bur, Tetrahedron 2007, 63, 5341-5378; g) T. Hashimoto, K. Maruoka, Handbook of Cyclization Reactions, S. Ma, Ed. Wiley-VCH: Weinheim,2010; h) S. Kanemasa, Heterocycles 2010, 82, 87-200; i) M.-Y. Han, J.-Y. Jia, W. Wang, Tetrahedron Lett. 2014, 55, 784-794; j) H. Suga, K. Itoh, in Methods and Applications of Cycloaddition Reactions in Organic Syntheses, N. Nishiwaki, Ed. Wiley: Weinheim, 2014, pp. 175-204.

[3] For recent reviews, see: a) Multicomponent Reactions; J. Zhu, H. Bienaymé Eds. Wiley-VCH, Weinheim, 2005; b) G. Guillena, D. J. Ramón, M. Yus, Tetrahedron: Asymmetry 2007, 18, 693-700; (c) L. H. Choudhury, T. Parvin, Tetrahedron, 2011, 67, 8213-8228; d) H. Pellissier, Adv. Synth. Catal. 2012 354, 237-294; e) S. S. Van Berkel, B. G. M. Bögels, M. A. Wijdeven, B. Westermann, F. P. J. T. Rutjes, Eur. J. Org. Chem. 2012, 3543-3559; f) G. van de Heijden, E. Ruijter, R. V. A. Orru, Synlett 2013, 24, 666-685; g) S. Brauch, S. S. van Berkel, B. Westermann, Chem. Soc. Rev., 2013, 42, 4948-4692; h) Multicomponent Reactions in Organic Synthesis, J. Zhu, M.-X. Wang, Eds. Wiley-VCH, Weinheim, 2014.

[4] For a review, see: B. M. Trost, Handbook of Green Chemistry 2012, 7, 1-33.

[5] Catalysis from A to Z: A Concise Encyclopedia; B. Cornils, W. A. Herrmann, M. Muhler, C.-H. Wong, Eds. Wiley-VCH, Weinheim, 2013.

[6] a) Methods and Applications of Cycloaddition Reactions in Organic Syntheses; N. Nishiwaki, Ed. John Wiley \& Sons, Inc., Hoboken, New Jersey, 2014 ; b) Cycloaddition Reactions in Organic Synthesis; S. Kobayashi, K. A. Jorgensen, Eds. Wiley-VCH, Weinheim, 2002.

[7] a) J. Mancebo-Aracil, C. Nájera, J. M. Sansano, Org. Biomol. Chem. 2013, 11, 662-675; b) J. Mancebo-Aracil, A. Cayuelas, C. Nájera, J. M. Sansano, Tetrahedron 2015, 71, 8804-8816.

[8] A new entry to azomethine ylides from glyoxals has been reported: N. K. Machamer, X. Liu, S. P. Waters, Org. Lett. 2014, 16, 4996-4999.

[9] The enantioselective version of this multicomponent synthesis has been reported: a) J. Mancebo-Aracil, C. Nájera, J. M. Sansano, Tetrahedron: Asymmetry 2015, 26, 674-678; b) A. Cayuelas, O. Larrañaga, C. Nájera, J. M. Sansano, A. de Cózar, F. P. Cossío, Tetrahedron 2016, in press.

[10] Also a high enantioselectivity can be achieved, for recent reviews of asymmetric 1,3-DC, see: a) H. Pellissier, Tetrahedron 2007, 63, 3235-3285; b) C. Nájera, J. M. Sansano in Topics in Heterocyclic Chemistry, A. Hassner, Ed., Springer-Verlag: Berlin-Heidelberg, 2008, vol. 12,pp. 117-145; c) L. Stanley, M.;Sibi, M. P. Chem.Rev. 2008, 108, 2887-2902; d) Álvarez-Corral, M.; Muñoz-Dorado, M.; Rodríguez-García, I. Chem. Rev. 2008, 108, 3174-3198; e) M. Naodovic, H. Yamamoto, Chem. Rev. 2008, 108, 3132-3148; f) C. Nájera, J. M. Sansano, M. Yus, J. Braz. Chem. Soc. 2010, 21, 377-412; g) M. Kissane, A. R. Maguire, Chem. Soc. Rev. 2010, 39, 845-883; h) J. Adrio, J. C. Carretero, Chem. Commun. 2011, 47, 6784-6794; i) J. Adrio, J. C. Carretero, Chem. Commun., 2014, 50, 12434-12446; j) C. Nájera, J. M. Sansano, J. Organomet. Chem. 2014, 771, 78-92; k) T. Hashimoto, K. Maruoka, Chem. Rev. 2015 $115,5366-5412$

[11] The 1,3-dipolar cycloadditions of azomethine ylides to aromatic dipolarophiles it has been reviewed: J. H. Ryan, Arkivoc 2015, (i), $160-183$.

[12] a) F. Shi, R.-Y. Zhu, W. Dai, C.-S. Wang, S.-J. Tu, Chem. Eur. J.2014, 20, 2597-2604; b) P.-J. Xia, Y.-H. Sun, J.-A. Xiao, Z.-F. Zhou, S.-S. Wen, Y. Xiong, G.-C. Ou, X.-Q. Chen, H. Yang, J. Org. Chem. 2015, 80, 11573-11579. 
[13] C.-S. Wang, R.-Y. Zhu, Y.-C. Zhang, F. Shi, Chem. Commun. 2015, 51, 11798-11801.

14] C. Yuan, H. Liu, Z. Gao, L. Zhou, Y. Feng, Y. Xiao, H. Guo, Org. Lett. 2015, 17, 26-29.

[15] a) Q.-H. Li, L. Wei, C.-J. Wang, J. Am. Chem. Soc. 2014, 136, 8685-8692; b) Z.-L. He, F. K. Sheong, Q.-H. Li, Z. Lin, C.-J. Wang, Org. Lett. 2015, 17. $1365-1368$.

[16] a) B.-C. Hong, A. K. Gupta, M.-F. Wu, J.-H. Liao, G.-H. Lee, Org. Lett. 2003, 5, 1689-1692; b) M. Potowski, J. O. Bauer, C. Strohmann, A. P. Antonchick, H. Waldmann, Angew. Chem. 2012, 124, 9650-9654; Angew. Chem., Int. Ed. 2012, 51, 9512-9516; c) Z.-L. He, H.-L. Teng, C.-J. Wang, Angew. Chem. 2013, 125, 3006-3010; Angew. Chem., Int. Ed. 2013, 52, 2934-2938; d) H.-Y. Tao, C.-J. Wang, Synlett 2014, $25,461-465$.

[17] a) H. Liu, Y. Wu, Y. Zhao, Z. Li, L. Zhang, W. Yang, H. Jiang, C. Jing, H. Yu, B. Wang, Y. Xiao, H. Guo, J. Am. Chem. Soc. 2014, 136, 2625-2629; b) H.-L. Teng, L. Yao, C.-J. Wang, J. Am. Chem. Soc. 2014, 136, 4075-4080.

[18] M. Nyerges, A. Viranyi, A. Pinter, L. Toke, Tetrahedron Lett. 2003, 44, 793-794.

[19] Rare [5+2] via rhodium-catalyzed reaction between pyridines and 1-sulfonyl-1,2,3-triazoles has been reported: D. J. Lee, H. S. Han, J. Shin, E. Yoo, J. Am. Chem. Soc. 2014, 136, 11606-11609.

[20] X.-Q. Hu, J.-R. Chen, S. Gao, B. Feng, L.-Q. Lu, W.-J. Xiao, Chem. Commun.2013, 49, 7905-7907

[21] a) D. Seebach, Angew. Chem. 1979, 91, 259-278; Angew. Chem. Int. Ed. Engl.1979, 18, 239-258; b) R. Brehme, D. Enders, R. Fernandez, J. M. Lassaletta, Eur. J. Org. Chem. 2007, 5629-5660.

22] S. Mantenuto, F. Mantellini, G. Favi, O. A. Attanasi, Org. Lett., 2015, 17, 2014-2017.

[23] a) O. A. Attanasi, L. De Crescentini, G. Favi, P. Filippone, F. Mantellini, F. R. Perrulli, S. Santeusanio, Eur. J. Org. Chem.2009, 3109-3127; b) A. Lemos, in Targets in Heterocyclic Systems-Chemistry and Properties, Vol. 14, O. A. Attanasi, D. Spinelli Eds., Società Chimica Italiana, Rome, 2010, p 1-18.

[24] For some examples on the reactivity of DDs see: a) J.-R. Chen, W.-R. Dong, M. Candy, F.-F. Pan, M. Jörres, C. Bolm, J. Am. Chem. Soc. 2012, 134, 6924-6927; b) C. Guo, B. Sahoo, C. G. Daniliuc, F. Glorius, J. Am. Chem. Soc. 2014, 136, 17402-17405; c) O. A. Attanasi, L. A. Campisi, L. De Crescentini, G. Favi, F. Mantellini, Org. Biomol. Chem., 2015, 13, 277-282; d) F. R. Perrulli, G. Favi, L. De Crescentini, O. A. Attanasi, S. Santeusanio, F. Mantellini, Eur. J. Org. Chem., 2015, 7154-7159; e) G. C. Senadi, W.-P. Hu, T.-Y. Lu, A. M. Garkhedkar, J. K. Vandavasi, J.-J. Wang, Org. Lett. 2015, 17, 1521-1524; f) Chen, J.; Jiang, Y.; Yu, J.-T.; Cheng, J. J. Org. Chem., 2016, 81, 271-275; g) G. Mari, G. Favi, L. De Crescentini, S. Santeusanio, O. A. Attanasi, F. Mantellini, Asian J. Org. Chem., 2016, 5, 705-709.

[25] a) Z. Chen, Q. Yan, Z. Liu, Y. Xu, Y. Zhang, Angew. Chem. 2013, 125, 13566-13570; Angew. Chem. Int. Ed. 2013, 52, 13324-13328; b) M. M. Uteuliyev, T. T. Nguyen, D. M. Coltart, Nature Chem. 2015, 7, 1024-1027; c) H.-W. Bai, Z.-J. Cai, S.-Y. Wang, S.-J. Ji, Org. Lett. 2015, 17, 2898-2901. d) L. De Crescentini, O. A. Attanasi, L. De Crescentini, G. Favi, S. Lillini, F. Ursini, F. Mantellini, Tetrahedron 2015, 71, 7282-7292; e) O. A. Attanasi, G. Favi, F. Mantellini, S. Mantenuto, G. Moscatelli, S. Nicolini, Synlett 2015, 26, 193-196; f) D. H. Miles, J. Guasch, F. D. Toste, J. Am. Chem. Soc. 2015, 137, 7632 7635; g) S. Mantenuto, S. Lucarini, M. De Santi, G. Piersanti, G. Brandi, G. Favi, F. Mantellini, Eur. J. Org. Chem., 2016, DOI: 10.1002/ejoc.201600210.

[26] For some recent examples on the synthesis of tetrahydropyridazines starting from DDs see: a) S. Gao, J.-R. Chen, X.-Q. Hu, H.-G. Cheng, L.-Q. Lu, W.-J. Xiao, Adv. Synth. Catal. 2013, 355, 3539-3544. b) O. A. Attanasi, L. Bianchi, M. D'Auria, F. Mantellini, R. Racioppi Curr. Org. Synth., 2013, 10, 631-639. c) M.-C. Tong, X. Chen, J. Li, R. Huang, H. Tao, C.-J. Wang, Angew. Chem. 2014, 126, 4768-4772; Angew. Chem. Int. Ed. 2014, 126, 4680-4684; d) J. Li, R. Huang, Y.-K. Xing, G. Qiu, H.-Y. Tao, C.-J. Wang, J. Am. Chem. Soc. 2015, 137, 10124-10127; e) X. Zhong, J. Lu, S. Luo, Org. Lett. 2015, 17, 1561-1564 f) L. Wei, C.-J. Wang, Chem. Commun. 2015, 51, 15374-15377; g) X. Li, K. Gai, Z. Yuan, J. Wu, A. Lin, H. Yao, Adv. Synth. Catal. 2015, 357, 3479-3484. h) R. Huang, X. Chang, J. Li, C.-J. Wang, J. Am. Chem. Soc. 2016, 138, 3998-4001. i) X.-L. Yang, X.-X. Peng, F. Chen, B. Han, Org. Lett. 2016, DOI: 10.1021/acs.orglett.6b00702

[27] R. Majer, O. Konechnaya, I. Delso, T. Tejero, O. A. Attanasi, R. Majer, O. Konechnaya, I. Delso, T. Tejero, O. A. Attanasi, S. Santeusanio, P.. A. Merino, S. Santeusanio, P. Merino, Org. Biomol. Chem.2014, 12, 8888-8901.

[28] H.-W. Zhao, H.-L. Pang, T. Tian, B. Li, X.-Q. Chen, X.-Q. Song, W. Meng, Z. Yang, Y.-Y. Liu, Y.-D. Zhao, Adv. Synth. Catal. 2016, DOI: 10.1002/adsc. 201600093.

[29] S. L. Schreiber, Science 2000, 287, 1964-1969.

[30] a) P. Karoyan, S. Sagan, O. Lequin, J. Quancard, S. Lavielle, G. Chassaing, in Targets in Heterocyclic Systems-Chemistry and Properties, Vol. 8, O. A. Attanasi, D. Spinelli Eds. Società Chimica Italiana, Rome, 2004, p 216-273; b) C. Nájera, J. M. Sansano, Chem. Rev. 2007, 107, 4584-4671; c) M. Calaza, C. Cativiela, Eur. J. Org. Chem. 2008, 3427-3448; d) S. Haider, Z. S. Saify, N. Begum, S. Ashraf, T. Zarreen, S. M. G. Saeed, World J. Pharm. Res. 2014, 3, 987-1024; e) C. Bhat, S. G. Tilve, RSC Adv. 2014, 4, 5405-5452; f) J. Li, H. Zhao, Y. Zhang, Synlett 2015, 26, 2745-2750, and references cited therein.

[31] a) A. Hasnaoui, J.-P. Lavergne, P. Viallefont, J. Heterocycl. Chem. 1978, 15, 71-75; b) W. M. Basyouni, K. A.-H. El-Bayouki, J. Chem. Res. 2005, 6, 356360; c) E. M. Afsah, M. Hammouda, M. M. Khalifa, E. H. Al-Shahaby, Z. Naturforsch., B: J. Chem. Sci. 2008, 63, 577-584.

[32] K. M. Elattar, M. A. Abozeid, I. A. Mousa, A. El-Mekabaty RSC Adv. 2015, 5, 106710-106753 and references cited therein

[33] a) L. Chen, G. M. Yang, J. Wang, Q. F. Jia, J. Wei, Z. Y. Du, RSC Adv., 2015, 5, 76696-76699; b) Y. Zi, K. Zhao, T. Shu, D. Enders, Synthesis 2016, 48, 238-244.

34] Gaussian, Inc., Gaussian 09, Revision B.01; Gaussian, Inc., Wallingford CT, 2009

35] a) O. A. Attanasi, P. Filippone, A. Mei, S. Santeusanio, Synthesis 1984, 671-672; b) O. A. Attanasi, P. Filippone, A. Mei, S. Santeusanio, Synthesis 1984, 873-874; c) O. A. Attanasi, L. De Crescentini, G. Favi, P. Filippone, F. Mantellini, S. Santeusanio, Synthesis 2002, 1546-1552; d) L. Preti, O. A. Attanasi, E. Caselli, G. Favi, C. Ori, P. Davoli, F. Felluga, F. Prati, Eur. J. Org. Chem. 2010, 4312-4320.

[36] Compound $7 \mathbf{a}$ is obtained as diatereoisomeric mixture. After a very careful chromatographic separation it was possible to isolate a small amount of the minor diastereoisomer that was fully characterized.

[37] Compound $7 \mathbf{b}$ is obtained as unseparable diatereoisomeric mixture. 